\title{
ANKRD24 Gene
}

National Cancer Institute

\section{Source}

National Cancer Institute. ANKRD24 Gene. NCI Thesaurus. Code C150169.

This gene plays a role in the modulation of protein-protein interactions. 